\title{
Publisher Correction: Sonogenetic control of mammalian cells using exogenous transient receptor potential A1 channels
}

\author{
Marc Duque (1), Corinne A. Lee-Kubli, Yusuf Tufail, Uri Magaram, Janki Patel (1D, Ahana Chakraborty (1), \\ Jose Mendoza Lopez (1D, Eric Edsinger, Aditya Vasan, Rani Shiao, Connor Weiss, James Friend \& \\ Sreekanth H. Chalasani (i)
}

Correction to: Nature Communications https://doi.org/10.1038/s41467-022-28205-y, published online 9 February 2022.

The original version of this Article contained an error in Fig. 4b, in which the figure labels 'Pre-US' and 'Post-US' were incorrectly positioned above the label 'Ultrasound $2.5 \mathrm{Mpa} 100 \mathrm{~ms}$ ' with right alignment to the figure panels, instead of below the label 'Ultrasound 2.5 Mpa $100 \mathrm{~ms}$ ' with central alignment to the figure panels. This has been corrected in both the PDF and HTML versions of the Article.

The original version of the Supplementary Information associated with this Article was missing Supplementary Tables 1 and 2 . The HTML has been updated to include a corrected version of the Supplementary Information.

Published online: 25 February 2022

\footnotetext{
(c) (i) Open Access This article is licensed under a Creative Commons Attribution 4.0 International License, which permits use, sharing, adaptation, distribution and reproduction in any medium or format, as long as you give appropriate credit to the original author(s) and the source, provide a link to the Creative Commons license, and indicate if changes were made. The images or other third party material in this article are included in the article's Creative Commons license, unless indicated otherwise in a credit line to the material. If material is not included in the article's Creative Commons license and your intended use is not permitted by statutory regulation or exceeds the permitted use, you will need to obtain permission directly from the copyright holder. To view a copy of this license, visit http://creativecommons.org/licenses/by/4.0/.
}

(c) The Author(s) 2022 